\title{
Rethinking global civil society and the public sphere in the age of pro-democracy movements
}

\begin{abstract}
Pro-democracy movements have recently emerged in various places worldwide. The Pots and Pans Revolution (Iceland), Arab Spring, 15M and the Occupy Movement, Yo Soy132, and the Gezi Park, Hong Kong or Nuit Debout protests, are all movements which, despite their differences, share a number of dynamics, links, frames and repertoires. Paradoxically, in the academic field, we have witnessed a strong critical positioning against the concept 'global civil society'. The objective of this article is to reflect on the utility of this concept once again in light of recent developments and to to respond to some sceptical positions. To meet this objective, a dialogue is established between civil society theories and progress made in the field of social movements. The public sphere notion (particularly its transnational dimension) becomes especially relevant for our discussion.
\end{abstract}

Key words: democracy, civil society, public sphere, social movements

In recent years, a number of pro-democracy movements have emerged worldwide which have had considerable impact on political and academic domains and which are directly linked to theoretical discussion of the polysemous and much-discussed global civil society concept. The Pots and Pans Revolution in Iceland (2008), the Arab Spring, 15M and Occupy Movement (2011), Yo Soy132 (2012), and the Gezi Park (2013), the Hong Kong Umbrella Revolution (2014) and Nuit Debout (2016) protests are just a few outstanding examples of citizen movements that have emerged.

Protests and manifestations have spread to different parts of the planet and have had a strong contagious effect and worldwide impact (Powell, 2015). Many studies have revealed the influence of Iceland and the Arab Spring on 15M (Flesher-Fominaya, 2014; Glasius \& Pleyers, 2013; Tormey, 2015) and the impact of $15 \mathrm{M}$ on the later Occupy and Yo Soy132 movements (Kaldor \& Selchow, 2013; Lawrence, 2013; Romanos, 2016). Neither can the Gezi Park, Hong Kong and the more recent French Nuit Debout protests be analysed as isolated cases. No matter how many differences these movements have (which they undoubtedly have), certain repertoires, demands and concerns are shared across these protest movements. This phenomenon has led theorists such as Glasius and Pleyers to discuss "the global moment" (2013), Flesher-Fominaya 
to describe these protest forms as "a global wave of protests" (2014), and Castells to stress the network characteristics of such transnational movements (2012). Many studies stemming from the field of social movement studies have examined the transnational and global aspects of these protests. However, it is pertinent to ask to what extent these movements and the studies that examine them may have a bearing on civil society theory, especially for the notion of global civil society and the sceptical positions that question it.

The intention of this article is to reflect theoretically on the concept of global civil society. Its objective is to closely examine and address, in light of recent developments, some of the criticisms regarding of this notion in recent decades. To this end, we re-examine a number of fundamental civil society studies and attempt to establish a dialogue with social movement theories. The public sphere notion (particularly its transnational dimension) becomes especially relevant for our discussion.

\section{A brief introduction to civil society and the global civil society concept}

Some authors in Western Europe stand out in the multifaceted, abundant reflection on polysemic civil society, after having reclaimed this term from progressive perspectives used in the last decades of the twentieth century (Kaldor, 2003; Feenstra, 2015). The objective of such proposals was to create forms of political transformation in which citizens are politically active and capable and the State is the frame that guaranteed rights. Such thinkers included Habermas, Keane, Barber, Kaldor, Alexander, Cohen and Arato, who, despite defending different normative civil society models, shared some basic elements in terms of the possibilities and roles that were assigned to this sphere (Edwards, 2004). These proposals understood civil society as a social structure in which citizens were actively engaged.

Civil society is considered a place of participation in which citizens make claims and participate in common debate about established regulations and power relations. Habermas, one of the main theorists of visions thought to be neo-Tocquevillian (Ehrenberg, 1999), very graphically expresses civil society's corrective task when he characterises it as having a "siege-type" influence on the systemic (political-economic) world (Habermas, 1996, p. 360). Keane, another main theorist of civil society thought (Hall, 1995), talks of civil society as "a thorn permanently in the political power's side" 
(Keane, 1988, 15) in which power relations are monitored (Keane, 2009). Finally, authors such as Barber trust in a civil society as a place capable of promoting the action of citizens responsible for, and committed to, the task of containing markets, civilising society and democratising governments (Barber, 1997).

The visions of civil society addresses various themes, including; discussions about the actors who make up civil society (eg. how the family and economic actors form part of civil society), the principles that define it (eg. is civil society defined only by solidarity relations, or also by strategic action?), and the exact functions attributed to it (eg. do they influence the political class, monitor it and/or influence the media/political agenda?). As a result of its polysemy, some theorists have considered that differences on the meaning of civil society are so profound that its theoretical and practical sense is lost (Wood, 1990).

However, several visions of civil society share meaningful similarities, especially those inspired by what is known as neo-Tocquevillian models (Ehrenberg, 1999). Civil society is understood as a structure that seeks to promote citizens' participation and political influence beyond the traditional electoral arena. Heterogeneous visions nevertheless share the idea of civil society as a non-State domain that nevertheless requires that the State guarantee free press, association, etc. Despite differences in the actors considered to form part of civil society, most conceptions undoubtedly include social movements, NGOs, consumer groups, and neighbour and consumer associations in this structure. In addition, non-violence is unanimously considered a key ideal principle expected of civil society.

However, the complexity of debate about civil society's role and function does not stop at this point. The increasing impact of globalisation and increased interconnectivity through new communication tools have extended polysemy and to the concept that has become known as global civil society. The growing transnationalisation of activism is considered evidence that global civil society is in the process of consolidation (Anheier Glasius \& Kaldor, 2001; Kaldor, 2003). There is also talk of 'globalisation from below', presented as an alternative to the "globalisation from above" process (Kaldor, Anheier \& Glasius, 2003; Falk, 1998). Keane defines the "new" global civil society as "a dynamic non-governmental system of interconnected socio-economic institutions that straddle the whole earth" (2003: 8), whose transnational attributes allow them to potentially "pluralise power and problematise violence" anywhere on the planet (Keane, 2003: 8). In general terms, global civil 
society is conceived as a transnational arena of politics, interaction and debate (Thörn, 2006; Del Felice, 2011) where we may integrate the pro-democracy movements.

However, the global civil society concept has been attended by a number of fundamental criticisms by sceptical theorists who believe that conceptualising this space of participation and discussion (now global in nature) is even more diffuse, undefined and incomprehensible than the already disputed "national" polysemous and confusing version of civil society (Bartelson, 2006). We now turn to review these criticisms.

\section{Sceptics of global civil society}

The meaning given to the global civil society concept is directly linked with its "lesser" version of civil society confined to the nation-state. Nonetheless, an important nuance of the global version of this concept is precisely the "loss" of its main reference point: the State. The original idea of civil society was defined as a space comprising different actors from the state political arena, who were capable of influencing the varied decision-making processes in each nation-state (Keane, 2009). Now the scope of such capacity of influence is transboundary, even global, in nature.

Not all theorists have viewed the theorising of civil society's global projection optimistically. Additionally, some perspectives point to imbalances that accompany civil society's globalisation process, while others question whether a global civil society is feasible without a "global State". The critical literature outlines a number of considerations about global civil society that can be divided into two main blocks. On the one hand, there are those that stress the shortcomings or imbalances that affect the actors of global civil society, where works such as those of Anderson and Rieff (2003) and Chandhoke $(2002 ; 2005)$ stand out. On the other hand, some considerations look closely at the problems that come with global civil society when there is no global governing system. For this, we look to the works of writers such as Brown (2000), Goodhart (2005), Bartelson (2006).

The first block of criticism centres on possible shortcomings concern conceptualisation of "global actors", specifically a lack of transparency and representation as basic problems. Accordingly, it is seen as problematic that "citizens do not vote for one type of civil society organisation or another as their representatives" and that "NGOs exist to reflect on their own principles" (Anderson \& Rieff, 2003, p. 29). Chandhoke also noted the unequal distribution of the world's resources and 
capacity to influence, or that "the majority of NGOs that are visible and influential in global civil society are based in the West" (Chandhoke, 2005, p. 361). This author suggests the control of "global civil society" by a handful of agents, not all of whom have the capacity or the resources to influence this sphere. Chandhoke warns that the danger of imbalances and inequality between North and South may lead to gaps in the representativeness of global civil society. In turn, she questions the extent to which these actors manage to promote participation while "people are disempowered rather than empowered" before "highly specialised and professionalised civil society actors" (Chandhoke, 2002, p. 47). These critics also indicate serious problems in relation to transparency and accountability of civil society's global actors.

A second block of criticism centres on issues that arise from the absence of consolidated institutions of global governance, which makes transferring the close relation between nation-state and civil society to the global arena impossible (Goodhart, 2005). The problems encountered vary. For instance, Brown indicates that a basic guarantor of a global civil society frame is missing, which causes "problems of a "lawand-order" type in the international system", and "restricts global civil society's functioning" (2000, p. 16). This lack of a global governance structure also entails that global civil society actors play roles that do not correspond to them. It has been stated that "global civil society's putative agents are obliged to become substitutes of a global State" (Brown, 2000, p. 17). The lack of a global political structure means that "nonState actors are enrolled to perform governance functions by virtue of their technical expertise, advocacy, and capacity" (Sending \& Neumann, 2006, p. 664). Thus, governance responsibilities taken on by non-state actors that have not even been selected for those tasks, who are not-accountable and not always efficient in their work. This may lead to more problems than solutions in a situation in which there is no global political structure (Brown, 2000).

However, the most forceful criticism of sceptics lies in denial of the possibility of a "global" civil society actually existing. From statist political theory perspectives, this notion appears to be an oxymoron (Scholte, 2007). On this point, Bartelson states that "if most accounts of global civil society assume this society to be distinct from governmental authority, where does this government authority then reside? Here theories of global civil society are silent" (Bartelson, 2006, p. 384). Sceptics consider that civil society theorists do not respond to the point about the absence of any global governmental authority (they state); paradoxically, the only thing that heterogeneous 
civil society models share (anchored to the national sphere) is their differentiation from the government. This silence leads sceptics to discuss the senselessness of the concept of global civil society and the impossibility of restricting those that are or are not its possible functions. According to Goodhart, "without global political institutions to translate the public will into law and policy, it is not clear what the political meaning of global deliberations is or should be" (Goodhart, 2005, p. 9). In short, it is believed that "it becomes unclear what exactly the democratic function of global opinion, discourse and deliberation might be" (Goodhart, 2005, p. 9). These criticisms deny the desirability, even the possibility, of global civil society's existence since "its democratic functions cannot work outside the democratic state" (Goodhart, 2005, p. 10).

Given the State's centrality in the original consideration of civil society, especially in neo-Tocquevillian visions, it is not surprising that doubts and criticisms regarding its global vision arise. However, the examples included at the start of this text on pro-democracy movements suggest that, at least a priori, we face the very actors about whom authors such as Habermas, Keane and others have theorised in recent decades within the theoretical framework of civil society (now the global civil society). What can be learned from the experience of such movements, and from studies in the social movement field? Studies such as these may help us to rethink global civil society.

\section{Social movements and the wave of global protests}

The "global moment" or the "wave of global protests", consolidated since 2011, presents many complex characteristics. Indeed, movements in places such as Iceland, Spain, Mexico, Brazil and France have varying internal actors and characteristics (and ideals). However, studies on such social movements have looked closely at common meaning structures and frames of movements, their transnational links, and their meaning for democracy theory. Glasius and Pleyers, for example, consider that "the diffusion of slogans, repertoires of action and meanings from Sidi Bouzid (Tunisia) and Cairo to Athens, Madrid, New York and Moscow has been a major feature of the global wave of movements that started in 2011" (2013, p. 547). These authors stress the existence of common elements between the North-South or East-West divides as the most relevant factor. It is important to see how studies by Kaldor and Scheuw (2013), Glasius and Pleyers (2013), Flesher-Fominaya (2014), Tormey (2015) and Gerbaudo (2017) on pro-democracy movements all appreciate the transboundary elements shared 
by civil society groups. As we see it, two key trends stand out in relation to rethinking global civil society:

- Revitalising domestic civil society

- Redefining the public sphere as global "arenas"

\section{Revitalising domestic civil society}

Debate about the concept of global civil society includes, as mentioned, discussion about the "real" level of transnationality acquires by both the actors that participate in it and their objectives. A dichotomy appears to be established between "national" actors and "global" actors. In the literature on global civil society, 'global actors' are conceived as groups simultaneously organised in different places around the world that debate shared concerns. However, it is not clear at what level that transnationality or what minimum number of countries is needed to (fully) become a global actor. Different studies have identified some organisations as examples of such actors, e.g., Greenpeace, Amnesty International, and Human Rights Watch. (Keane, 2003), whose links go beyond those of a State and whose demands also stretch further than national frontiers. Notwithstanding, recent studies on pro-democracy social movements provides useful information to help us reconsider this categorical dichotomy between national and global actors and the level of organisation and the institutional arena actors' demands address.

The international study by Glasius and Pleyers on pro-democracy movements, consolidated as of 2011, points to a "global generation" characterised as "precarious"; capable of using a number of digital tools; and sharing slogans, concerns, repertoires of action and identities (Glasius \& Pleyers, 2013, p. 549). At the same time, their work also includes, in line with other contemporary studies in the social movements field:

"The national context, we will argue, is actually more important than a decade ago as more demands are made on local and national authorities. Moreover, within their own context, each of these movements - be it the Egyptian revolution, Spanish Indignados or Occupy Wall Street- is broad and heterogeneous, bringing together a wide range of activists, both in terms of generations and of activist cultures" (Glasius \& Pleyers, 2013, p. 549). 
Glasius and Pleyers's work on different pro-democracy movements shows that, despite sharing key aspects, the governments of the respective nation-states are a central target of movements. A macro-study conducted in Europe by Kaldor and Selchow concludes that "Europe is invisible" in activists" eyes. They specifically note that "the question of Europe was almost never raised by our interviewees and only tended to be addressed in answer to direct questions" (Kaldor \& Selchow, 2013, p. 19). A detailed analysis by Bourne and Chatzopoulou of recent movements in Greece and Spain also concludes that the "data show that social movement activity can be largely characterised as domestic in orientation. In both Spain and Greece, social movements targeted domestic actors in their protests" (2015, p. 54). In a study by Flesher-Fominaya on Iceland, Tunisia, Egypt, Spain and USA (Occupy), the author also concludes that the different "global wave of protests" movements present national specificities and nationally rooted political demands linked to the lack of a "transnational organisational infrastructure" (2014, p. 183). However, this author also appreciates key transnational elements between given contexts that mark the essence of this "global wave". Flesher-Fominaya stresses that a specific transnational diffusion process occurs in various contexts, among which "a global circulation of information, resources, ideas, practices, tactics and peoples" has been promoted (2014, p. 184).

These studies allow us to recognise the importance of the domestic or local issues in these movements, as well as their transnational links, solidarity and influences. Since 2010, we have witnessed slogans that move around the world ("We are all Khaled Said", "Real Democracy Now", "We are the 99\%", and "Global Debout"), shared identities being consolidated ("indignados", "anonymous"), the sudden appearance of common repertoires (Occupations, Technopolitics, etc.), and the use of new tools to share ideas and strategies. Similarly, all these movements share a concern to re-define and re-think democracy beyond its representative structure (Keane, 2013; FlesherFominaya, 2014; Tormey, 2015; Feenstra et al., 2017). In short, we face a trend in which a domestic civil society is not only revitalised but is also another trend redefining the public sphere as global "arenas". An aspect that is studied in deep in this special issue by Bourne (2017) and García Agustín (2017).

Redefining the public sphere as global "arenas" 
Studies on social pro-democracy movements stress not only the importance of domestic policy-making but also transnational trends, which are particularly relevant for defining the public sphere. A paradigmatic and illustrative example of this trend can be found in the political struggle of the Spanish PAH platform (Platform for People Affected by Mortgages), one of the best know activist groups from 15M. PAH is an organisation involved in the movement against evictions. This network has a decentralised structure and is present in more than 145 Spanish cities and towns (González-García, 2015). Over 5 years it has pressured the Spanish government to amend Spanish law on mortgages. It is a civil society actor that has extended its pressure to multiple territorial levels. Locally, it has placed claims in Town Halls for them to declare their towns evictionfree. Nationally, it has presented and lobbied through popular legislative initiatives, for an alternative to the existing law on mortgages. In Europe, it has sought, and found the support of, the European Parliament and the EU Court of Justice in its demand that the Spanish Government amends the Spanish law on mortgages. PAH works as a network and is coordinated with other European anti-eviction platforms from Italy, Germany, France, UK, etc. Their actions, repertoires, slogans and demands are reproduced in other contexts, with clear parallels in some places (Ordóñez, Feenstra \& Tormey, 2015). PAH promotes a network policy that blurs the divisions of what is local, national and transnational. As it does so, it has a direct influence on public spheres where alternative discourses emerge. Civil society's pressure is exercised not only on a single focal point of governmental power but at many levels.

We can appreciate this complex multidimensional characterisation, which particularly impacts on the contours of the public sphere, in relation to the more recent Nuit Debout movement, where $15 \mathrm{M}$ activists offered their technical support and "knowhow". This trend has been previously documented for former movements such as Occupy, which has been supported since 2011 by $15 \mathrm{M}$ activists who act as "brokers" that facilitate the "diffusion of particularly complex innovations related to the organisation of social movements and the development of collective action repertoires" (Romanos, 2016, p. 248). As with $15 \mathrm{M}$ in 2011, movements managed to introduce themes into the public and media-based agenda (eg. eviction problems, the need to include new participation mechanisms, inefficiency of key State institutions, etc.). Nuit Debout has also introduced new themes in public (and media) discourse (eg. labour reform, financial market power, meaning of political participation, etc.). 
Citizen platforms such as PAH or the "movements of the squares" have become consolidated in different countries and have major transnational elements that form part of their goal of influencing and defining the public sphere. Gerbaudo concludes that the achievement and real success of these movements lie in having reclaimed public space and involving the citizenry in public discussions about economic and political inequality and that this has facilitated a profound cultural change through public rituals (2017). Different pro-democracy movements have consolidated counterpublics that offer alternative political discourses and re-think the set rules of the game in public debates (Fraser, 1992). Accordingly, Kaldor and Scheuw consider that these movements are "projects of collective re-imagining of democracy" where practices and "its relation to the everyday, to human lives" are re-thought (Kaldor \& Selchow, 2013). Pleyers concurs when noting that despite the national differences of these movements, they "provide alternative meanings to the crisis and reclaim a more democratic society" (Pleyers, 2012).

These movements certainly foster the consolidation of alternative discourses with high resonance (Tormey, 2015). It is worth noting, therefore, the conclusions drawn by Kaldor and Selchow when they state that "unlike previous mobilisations and protests, they seem to have struck a chord in the mainstream; they generate a sense of public excitement wherever they happen” (2013, p. 79). Pro-democracy movements have repeatedly had the ability to influence the public sphere in a number of respects: Diffusing repertoires of protest manifest via many channels, including brokers, new media, mass media, etc. (Lawrence, 2013; Romanos, 2016); enhancing the relevance of new communication tools to alter classic political intermediation processes (Tormey, 2015; Subirats, 2012); influencing the mass media through media-based "hacking"; organising protests as if they were shows (Flesher-Fominaya, 2014; Micó \& Casero, 2014); consolidating collective shared identities (Gerbaudo \& Treré, 2015; Monterde et al., 2015; Toret, 2013); and establishing occupations as places to practice in, to experiment in and for democratic "incubators" (Postill, 2015; Gerbaudo, 2017). These are just some of the trends that define a transnational public sphere and as such it is plausible to consider that we are witnessing movements that form part of global civil society.

\section{Rethinking global civil society in the pro-democracy movements era}


Those sceptical about global civil society identify important criticisms that are worth considering. Problems such as lack of transparency and plurality, outlined by Chandhoke, Anderson and Rief, remind us of the critical nature of the civil society concept. As Chambers and Kopstein have examined in detail, civil society responds to a number of normative (ideal) principles that make it much more than merely non-State actors; conversely, terrorist or xenophobic groups would be included in this category, without distinguishing between bad and good civil society actors (Chambers \& Kopstein, 2001; see also Keane, 1998; García Marzá, 2008). Even though some recent studies draw different conclusions about Chandhoke's criticisms of the lack of transparency in relation to global civil society (Piewitt, Rodekamp \& Steffek, 2010), her works reminds us of the importance of civil society actors, in their institutional dimension, meeting certain minimum principles of transparency, openness, democracy, etc. that enable us to appreciate how civil society forms part of a social sphere that aims to closely examine and extend participation in democracy practice.

Nonetheless, criticisms that question the role, the desire for, and even the possibility of the existence of, global civil society - essentially those which stress the problems of having no global political "state" to accompany global civil society (Brown, 2000; Goodhart, 2005; Bartelson, 2006) - are more problematic. These criticisms, which question the central argument of those who have theorised civil society, are based on a limited understanding of the civil society theory. We believe that there are two basic responses to global civil society sceptics in this regard:

\section{The growing "glocalisation" process}

Many studies have examined the increasing relevance of actors who go beyond national frontiers to influence the political agenda, to consider alternative discourses or to propose political changes at different (local, national or international) levels (Della Porta \& Mattoni, 2014). Studies on civil society and International Summits (Harrebye, 2011), the world's struggle against famine (Mati, 2009) or the transnational dimension of struggles against regimes such as Apartheid (Thörn, 2006), are some examples of these transnational dynamics of civil society. To these, it is worth adding, as we explained earlier, is the sudden appearance of a wave of protests and forms of political expression that we can classify as transnational or global. Undoubtedly, there are excellent reasons to argue that as a result of globalisation and better connections, actors 
overcome separation imposed by national borders. Those sceptical about global civil society are aware of this trend, but they retain their criticism that there is no alter ego of global civil society, that is, there is no global State. We argue that these proposals stem from the perspective of statist political theory, which understood civil society and State concepts inseparable (as well as global civil society and "Global state").

It is true that the absence of a global political state has its consequences and impacts civil society/societies, especially insofar as democracy is lacking. Moreover, when civil society actors perform functions that correspond to governments for which they have not been selected, they can be considered problematic. However, unlike the sceptics argument, global civil society has not arisen as a solution to the question (and current shortage) of global governance (of which global civil society only forms one part). Global civil society theories indicate an increasing blurring of civil society's spatial boundaries in terms of organisation, networks and political objectives. Prodemocracy movements are yet another example of how pressure is applied at many levels: local, national and transnational. They may have the objective of redefining politics in their national democratic systems (where parliamentary decisions are made), but they do so in concert with other contexts and are influenced and inspired by other countries. These pressures also affect transnational political actors (e.g., EU or IMF institutions) and multinational companies as they are evident focal points of economic and political power. Just as the transnational character of organisations such as Amnesty International, Greenpeace, and Doctors Without Frontiers can be appreciated, the prodemocracy movements also acquired a growing transboundary nature. For example, on 15 May 2016, which was the $5^{\text {th }}$ anniversary of the Spanish 15M's emergence, the French Nuit Debout collaborated closely in organising a Global Debout, which spread to 190 European cities, including Paris, Amsterdam, Barcelona, Madrid and Berlin. In the international call, the slogan read "The struggle for a better world is Global and without borders, let us construct together a global spring of resistance!"1. As Kaldor, Scheuw, Pleyers, Glasius, etc., point out, these movements were not as massive in size as other former protests, such as those against the Iraq war, but they all (15M, Occupy, YoSoy132, etc.) had a strong impact and influence on defining themes within the public sphere. This leads us to the second key idea.

\footnotetext{
${ }^{1}$ \#NuitDebout's International call https://nuitdebout.fr/globaldebout/en/globaldebout-mobilisation-may-15/ https://spanishrevolution.wordpress.com/2016/04/16/llamada-internacional-de-nuit-debout/
} 
Sceptical proposals generally consider that the only place where heterogeneous visions on civil society coincide is in relation to the State; a State upon which pressure is placed peacefully. Sceptics seem to take the view that "national" civil society has the nation state as its inseparable partner, and global civil society must have a "state" or "political system" that is also "global". However, this is founded on an imprecise vision of civil society's role and meaning. Accordingly, global civil society sceptics disregard the relation between global civil society and the conception of the public sphere. Civil society is understood by authors such as Habermas, Keane, Cohen, Arato and others as not only the complement or alter ego of the State but also as a place that influences and generates the formation of the public sphere. Habermas and Keane also define this quite clearly in relation to a democracy model, which is deliberative for the former (Habermas, 1996) and monitory for the latter (Keane, 2009; 2013).

Habermas defines the public sphere as "a network of communication information and points of view; the streams of communication are, in the process, filtered and synthesized in such a way that they coalesce into bundles of topically specified public opinions" (Habermas, 1996, p. 306). The key to Habermas's deliberative model lies in the capacity of actors (civil society) to debate under ideal conditions of equality, plurality and inclusion on themes of public interest, actors who are ultimately capable having an influence on "administrative power" via the public sphere. Administrative power has control of binding decision making.

Keane, defines the public sphere as a physical or media-based place where civil society questions and "debunks power relations", and extends civil society's possibilities in several directions (Keane, 1998, p. 169; 2009). On the one hand, he attributes this not only to its role of influencing but also to the function of determining administrative power by monitoring and public scrutiny, especially when actors who hold power exercise this capacity arbitrarily and abusively. On the other hand, unlike Habermas, Keane extends civil society's pressure or "siege" (through the public sphere) not only to political power but also to other powers, e.g., economic ones. Both authors conclude that they consider civil society to be a key area in the definition and incorporation of new themes in public discussion. 
The ever-increasing importance of new communication tools and the development of globalisation have forced the public sphere to acquire a more complex and transboundary nature. Studies into pro-democracy movements allow us to appreciate just how civil society revitalises the public sphere's role in many directions, and how it is not cloistered and only framed within the nation state. The analyses of prodemocracy movements allow us to appreciate how the concept of global civil society helps to introduce new themes into the public sphere, creating new frames and solidarities transnationally, and how it also promotes critical reflection within society itself. State institutions (either national or international) are not the only interlocutors of global civil society. Civil society itself makes sense in that it seeks to discuss and deliberate, through public sphere/s, about its own conceptions, values, ways of life, consumer habits, etc. It is important to stress global civil society's multidirectional nature, which addresses both state institutions and society (Cohen \& Arato, 1992).

We conclude that in the era of pro-democracy movements, global civil society offers us a valid and necessary theoretical framework to be able to understand the present revitalisation of the domestic civil society, which is organised and addresses numerous levels (local, national and global) and to re-think the ideal conditions that accompany (or must accompany) democracy and its basic pillars.

\section{References}

Anderson, K. \& Rieff, D. (2005). Global civil society: A sceptical view. In H. Anheier, \& M. Glasius (Eds.) Societies: Dilemmas of Institutionalization (pp. 211-238). London: Sage.

Anheier, H., Glasius, M. \& Kaldor, M. (2001). Introducing global civil society. In G. Anheier \& M. Kaldor (Eds.) Global Civil Society 2001 (pp. 3-22). Oxford: Oxford University Press.

Barber, B. (1997). Un lugar para todos. Barcelona: Paidós.

Bartelson, J. (2006). Making Sense of Global Civil Society. European Journal of International Relations, 12(3), 371-395.

Bourne, A. (2017). Social movements and the transnational transformation of public spheres. Journal of Civil Society,

Bourne, A. and Chatzopoulou, S. (2014). Europeanization and Social Movement Movilization During the European Sovereign Crisis: The Cases of Spain and Greece. Recerca, 17, 33-60.

Brown, C. (2000). Cosmopolitanism, world citizenship and global civil society. Critical Review of International Social and Political Philosophy, 3(1), pp. 7-26.

Castells, M. (2012). Networks of outrage and hope: Social movements in the Internet age. Cambridge: Polity.

Chambers, S. \& Kopstein, J. (2001). Bad civil society. Political Theory, 29(6), 837-865.

Chandhoke N. (2005). How Global is Global Civil Society? Journal of World-Systems Research, xi (2), 355-371.

Chandhoke, N. (2002). The limits of global civil society. In M. Glasius, M. Kaldor \& H. Anheier (Eds.). Global civil society 2002 (pp. 35-52). Oxford: Oxford University Press.

Cohen, J. \& Arato, A. (1992). Civil Society and Political Theory. Cambridge: MIT Press.

Del Felice, C. (2011). Transnational Activism and Free Trade. Exploring the Emancipatory Potentials of Global Civil Society. Voluntas, 23, 302-327 
Della Porta, D. \& Mattoni, A. (2014). Spreading Protest. Social movements in the Time of Crisis. Colchester: ECPR Press.

Della Porta, D. (2013). Can Democracy Be Saved? Participation, Deliberation and Social Movements. Cambridge: Polity.

Dryzek, J. S. (2012). Global Civil Society: The Progress of Post-Westphalian Politics. Annual Review of Political Science, 15, 101-119.

Edwards, M. (2004). Civil society. Cambridge: Polity Press.

Ehrenberg, J. (1999). Civil society. The critical history of an idea. New York: New York University Press.

Falk, R. (1998). Global civil society: Perspectives, initiatives, movements. Oxford Development Studies, 26(1), 99-110.Feenstra, R. A. (2015). Activist and Citizen Political Repertoire in Spain: A Reflection Based on Civil Society Theory and Different Logics of Political Participation. Journal of Civil Society, 11(3), 242-258.

Feenstra, R. A., Tormey, S., Casero-Ripollés, A., \& Keane, J. (2017). Refiguring democracy:

The Spanish political laboratory. London: Routledge.

Flesher-Fominaya, C. (2014). Social movements and globalizations. How portest, occupations and uprising are changing the world. New York: Palgrave.

García Agustín, O. (2017) European counterpublics? DiEM25, Plan B and the agonistic European Public Sphere. Journal of Civil Society, $x x x$

García Marzá, D. (2008). Sociedad civil: una concepción radical. Recerca, 8, 27-46.

Gerbaudo P. \& Treré E. (2015) In search of the 'we' of social media activism: introduction to the special issue on social media and protest identities. Information, Communication \& Society. 18(8), 865-871.

Gerbaudo, P. (2017). The Mask and the Flag: The Rise of Citizenism in Global Protest. London: Hurst Publishers.

Glasius, M. \& Pleyers G. (2013). The Global Moment of 2011: Democracy, Social Justice and Dignity. Development and Change, 44(3), 547-567.González-García, R. G. (2015). El moviment per l'okupació i el moviment per l'habitatge: semblances, diferències i confluències en temps de crisi. Recerca, 17, 85-106.

Goodhart, M (2005) Civil Society and the Problem of Global Democracy. Democratization, 12(1), pp. 1-21.

Habermas, J. (1996). Between Facts and Norms. Contributions to a Discourse Theory of Law and Democracy. Cambridge: MIT Press.

Hall, J. A. (1995). Civil society, theory, history, comparison. Cambridge: Polity Press.

Harrebye, S. (2011). Global Civil Society and International Summits: New Labels for Different Types of Activism at the COP15. Journal of Civil Society, 7(4), 407-426.

Kaldor, M. \& Selchow, S (2013). The 'Bubbling Up' of Subterranean Politics in Europe. Journal of Civil Society, 9(1), 78-99.

Kaldor, M. (2003). The idea of global civil society. International Affairs, 79(3), 583-593.

Kaldor, M., Anheier H. \& Glasius (eds.) (2003). Global civil society. Oxford: Oxford University Press.

Keane, J. (1988). Democracy and civil society. London: Verso.

Keane, J. (1998). Civil Society: Old Images, New Visions. Oxford: Polity Press.

Keane, J. (2003). Global civil society? Cambridge: Cambridge University Press.

Keane, J. (2009). The life and death of democracy. London: Simon \& Schuster.

Keane, J. (2013). Democracy and media decadence. Cambridge: Cambridge University Press

Kumar, K. (2008). Civil Society, Globalization, and Global Civil Society. Journal of Civil Society, 4(1), 15-30.

Lawrence, J. (2013). The international roots of the $99 \%$ and the 'politics of anyone'. IC Revista Científica de Información y Comunicación, 10, 1-19.

Mati, J. M. (2009). A Cartography of a Global Civil Society Advocacy Alliance: The Case of the Global Call to Action against Poverty. Journal of Civil Society, 5(1), 83-105.

Micó, J. L., y Casero-Ripollés, A. (2014). Political activism online: Organization and media relations in the case of $15 \mathrm{M}$ in Spain. Information, Communication and Society, 17(7), $858-871$. 
Monterde, A., Calleja-López, A., Aguilera, M., Barandiaran, X. \& Postill, J. (2015). Multitudinous identities: a qualitative and network analysis of the $15 \mathrm{M}$ collective identity. Information, Communication and Society, 18(8), 930-950.

Ordóñez, V., Feenstra, R. A., \& Tormey, S. (2015). Citizens against Austerity: a Comparative Reflection on Plataforma de Afectados por la Hipoteca (PAH) and Bündnis Zwangsräumung Verhindern (BZV). Araucaria, 17(34), 133.

Piewitt, M., Rodekamp, M. \& Steffek, J. (2010) Civil Society in World Politics: How Accountable are Transnational CSOs? Journal of Civil Society, 6(3), 237-258.

Pleyers, G. (2012). Beyond Occupy: Progressive activists in Europe. Open Democracy. Retrieved from: https://www.opendemocracy.net/geoffrey-pleyers/beyond-occupyprogressive-activists-in-europe (Accessed 11 July 2016).

Postill, J. (2015, in press) "Field theory, media change and the new citizen movements: the case of Spain's 'real democracy turn', 2011-2014”. Mediterranean Politics.

Powell, F. (2015). The Psych-politics of Austerity: Democracy, Sovereignty and Civic Protest. Recerca. Revista de Pensament, 17, 15-31.

Romanos, E. (2016). Immigrants as brokers: dialogical diffusion from Spanish indignados to Occupy Wall Street. Social Movement Studies, 15(3), 247-262.

Scholte, J. A. (2007). Civil Society and the Legitimation of Global Governance. Journal of Civil Society, 3(3), 305-326.

Schumpeter, J. A. (2003). Capitalism, Socialism and Democracy. London: Routledge.

Seligman, A. (1992). The idea of civil society. Princenton: Princeton University Press.

Subirats, J. (2012). Algunas ideas sobre política y políticas en el cambio de época: Retos asociados a la nueva sociedad y a los movimientos sociales emergentes. Interface, 4(1), 278-286.

Thörn, H. (2006). The Emergence of a Global Civil Society: The Case of Anti-Apartheid. Journal of Civil Society, 2(3), 249-266.

Toret, J. (coord.) (2013). Tecnopolítica: la potencia de las multitudes conectadas. El sistema red $15 M$, un nuevo paradigma de la política distribuida. Barcelona: UOC

Tormey, S. (2015) The End of Representative Politics. Cambridge: Polity.

Wood, E. M. (1990), The uses and abuses of Civil Society. Socialist Register, 26, 60-84. 